\title{
Procedimento construtivo e TRATAMENTO DOS MEIOS EXPRESSIVOS: CONCEPC̄̃̃ES SOBRE $O$ CONTO EM Edgar Allan Poe a partir da leitura crítica de Nathaniel Hawthorne
}

ChaRles Kiefer

Pontifícia Universidade Católica do Rio Grande do Sul

\section{Resumo}

Este ensaio rastreia a poética do conto de Edgar Allan Poe a partir das resenhas críticas que fez de Nathaniel Hawthorne, no alvorecer do capitalismo e da modernidade literária. As noções de eixo dos procedimentos construtivos e eixo dos meios expressivos, derivadas do formalismo russo, são aplicadas aqui ao próprio trabalho de Edgar Allan Poe, que funcionou como par dialético de Nathaniel Hawthorne.

\section{Abstract}

This essay traces the poetics of the short story in Edgar Allan Poe based on his critical reviews of Nathaniel Hawthorne, at the dawn of capitalism and literary modernity. The notions of the axes of constructive procedures and of expressive means, derived from Russian formalism, are applied here to Poe's own work, which operated as a dialectical pair of Nathaniel Hawthorne.

\section{Palavras-chave}

Poética do conto, procedimentos construtivos, meios expressivos, Edgar Allan Poe, Nathaniel Hawthorne.

\section{Keywords}

Poetry of language, constructive principles, expressive means, Edgar Allan Poe, Nathaniel Hawthorne. 
Um artista que não ensina nada a outros artistas não ensina nada a ninguém, disse Walter Benjamin. ${ }^{1}$ Antes de ensinar a seus compatriotas - por quem, aliás, foi ignorado por muito tempo ${ }^{2}$-, Edgar Allan Poe, ainda no século XIX, influenciou o trabalho de escritores franceses, italianos, espanhóis, portugueses, alemães e russos, e, já no século XX, de mexicanos, colombianos, peruanos, venezuelanos, brasileiros, argentinos e uruguaios. Na França, os simbolistas, que se reuniam no apartamento de Stephane Mallarmé, elegeram o autor de "O corvo" como seu profeta. ${ }^{3}$ Mallarmé traduziu os poemas do escritor norteamericano; Charles Baudelaire traduziu seus contos, num trabalho de dezesseis anos, reunindo-os numa antologia que denominou de Histoires extraordinaires e com isso o divulgou em outras nações, e atingiu, assim, a Sibéria, onde foi traduzido por Dostoievski, ${ }^{4}$ e a pampa argentina, onde influenciou Jorge Luis Borges e Julio Cortázar, entre outros. Se Aristóteles foi o responsável, na Antiguidade Clássica, pela produção da primeira reflexão séria sobre a arte de fazer tragédias, Poe, nos tempos modernos, deve ser considerado o primeiro escritor a refletir com rigor sobre a arte da contística. Nas resenhas dedicadas a Twice-told tales, de seu conterrâneo Nathaniel Hawthorne, estabeleceu os fundamentos de uma poética do gênero.

No texto de abril de 1842, publicado na Graham's Magazine, ${ }^{5}$ Edgar Allan Poe elabora uma síntese de suas concepções a respeito do conto. A primeira consideração aparece já no parágrafo inicial. Segundo o autor7, esse gênero de narrativa fornece "a melhor oportunidade em prosa para se exibir o melhor talento" e prossegue dizendo que ele "possui vantagens peculiares" sobre o romance, além de ser "obviamente uma área mais refinada do que o ensaio", chegando "a ter pontos de superioridade sobre a poesia". Nas resenhas seguintes, retomará tais tópicos.

Excetuando-se os contos do livro de Washington Irving, Tales of a traveler, Poe não reconhece na contística americana de sua época produções "habilidosas" e que pudessem ser consideradas "obras de arte". Sem poder passar à análise literária propriamente dita da obra, já que o espaço de que dispõe naquele número

${ }^{1}$ BENJAMIN, Walter. Textos de Walter Benjamin. São Paulo: Ática, 1991.

${ }^{2}$ T. S. Eliot (Ensaios escolhidos. Lisboa: Cotovia, 1992, p. 147) encontrou em suas obras uma "escrita negligente, pensamento pueril sem o apoio de leitura vasta e erudição profunda, experiências fortuitas em vários tipos de escrita, principalmente sob pressão de necessidades financeiras, sem perfeição de qualquer pormenor", mas reconheceu que o prestígio do escritor, especialmente sobre Charles Baudelaire, Stephane Mallarmé e Paul Valery, era "perturbante". Talvez como desculpa por não compreendê-lo devidamente, afirmou ainda que todos nós "gostamos de acreditar que compreendemos os nossos próprios poetas melhor do que qualquer estrangeiro pode compreender, mas penso que devíamos estar preparados para considerar a possibilidade de que estes franceses viram alguma coisa em Poe que leitores de língua inglesa deixaram escapar". Para Edmund Wilson (11 ensaios. São Paulo: Companhia das Letras, 1991, p. 41), tanto Poe quanto Hawthorne e Melville "coagulavam suas fantasias numa prosa viscosa, emperrada". Bret Harte (Maravilhas do conto norte-americano. São Paulo: Cultrix, 1963, p. 12), também contista, referindo-se a Poe, Hawthorne e Irving, disse que "suas obras não são a história curta de nossos dias. Não são apropriadas à vida, costumes ou pensamentos americanos. Não participam, no seu desenvolvimento e tendências, da observação e experiência do modo de ser da América, nem trataram de seguir suas idéias ou de entender sua maneira peculiar de expressar-se, que consideravam vulgar. Também não simpatizavam com os dramáticos contrastes e surpresas que são o mais assombroso da civilização americana, nem consideravam as modificações do meio e os limites geográficos, chegando mesmo à ignorância de sua geografia".

${ }^{3}$ Lúcia Santaella (Os melhores contos de Edgar Allan Poe. São Paulo: Círculo do LIvro, 1987, p. 150) afirma que "os franceses receberam da teoria e práticas poeanas as primeiras lições sobre o poder de sugestão do indefinido como elemento de verdadeira poeisis, isto é, a construção precisa do impreciso, que os poetas simbolistas levariam, na França, às últimas conseqüências. Já na América Latina deste nosso século, por outro lado, é impossível pensar o boom da prosa ficcional dita "fantástica" sem pensar em E. A. Poe".

${ }^{4}$ Segundo Lubov Breit Keefer (Teoría del cuento: tres ensayos. Mérida: Universidad de Los Andes, 1967, p. 232), A. S. Suvórin, amigo de Anton Tchecov, e editor da Revista Nóvoie Vriémia, teria traduzido mal o escritor bostoniano.

${ }^{5}$ Julio Cortázar, no prefácio à tradução dos contos de Edgar Allan Poe, Obras em prosa, publicadas em Porto Rico, em 1956, considerou sensacional a contribuição do norte-americano para essa revista, da qual foi diretor artístico, já que, entre fevereiro de 1841 e abril do ano seguinte, o número de assinantes saltou de cinco mil para quarenta mil (CORTÁZAR, Julio. Obra crítica. Rio de Janeiro Civilização Brasileira, 1999, p.296). 
da revista é muito curto, debruça-se sobre o seu título, condenando Hawthorne pelo que considera uma escolha equivocada, já que esses contos reeditados "não deveriam ter sido chamados de Twice-told tales", pois se "na primeira edição completa foram contados duas vezes, é claro que agora são contados três vezes". Em 1837, Hawthorne recolhera dezoito contos, que já havia publicado em jornais e revistas - Salem Gazette, The Token, New-England Magazine, United States Magazine and Democratic Review, The Knickerbocker e New York Montly Magazine - no volume que, por esse motivo, intitulou Twice-told tales. A resenha de Poe, no entanto, refere-se à edição revista e ampliada em vinte e um contos e publicada em dois volumes em 1842, em Boston, por James Munroe and Company. O segundo problema detectado por Poe é que o livro de Hawthorne não seria composto somente de contos, mas também de alguns sketches. Assim, depois de apontar o que lhe parecem os defeitos mais graves, dedica-se a elogiar a obra, especialmente no que diz respeito ao estilo, "de uma pureza singular", e ao tom, "particularmente impressionante - selvagem, tristonho, pensativo e em completa harmonia com seus temas". Embora se opusesse à insuficiente diversidade temática apresentada por Hawthorne, considera extraordinária sua originalidade, "tanto em relação ao episódio quanto à reflexão".

Os elementos de uma poética do conto, esboçados nessa primeira resenha o tour-de-force do contista, as vantagens do conto sobre o romance, o ensaio e a poesia, a recusa do tom melodramático, a ausência de sutileza, os excessos do realismo fotográfico, a adequação do título, a pureza de estilo, a harmonização entre tom e tema, a diversidade de assuntos e a valorização da originalidade — retornam, na segunda e na terceira resenhas, com maior riqueza de detalhes e aprofundamento.

Em maio de 1842, Poe $^{7}$ torna a criticar o título da obra, mas acrescenta um dado sobre o burilamento da composição: "Mencionamos esses assuntos principalmente por causa de sua discrepância em relação à precisão e ao acabamento tão marcado que distinguem o corpo do trabalho". Depois de analisar com brevidade os ensaios de Hawthorne, apresenta a tese da unidade de efeito ou de impressão, que retomará com mais rigor, em 1846, em A filosofia da composição, na qual explicará, a posteriori, o processo de criação de seu poema The raven:

É necessário apenas dizer a respeito deste assunto que, em quase todas as categorias de composição, a unidade de efeito ou de impressão é um ponto da maior importância. Além do mais, está claro que essa unidade não pode ser totalmente preservada em produções cuja leitura não possa ser completada de uma assentada. ${ }^{8}$

Poe condena a "brevidade excessiva", que deriva para o epigramatismo, e a "extensão excessiva", que considera um pecado. ${ }^{9}$ A nova era pode perdoar a reticência e o subentendido, mas não a prolixidade e a dissertação. Assim, da mesma forma que um poema rimado, o conto em prosa é o tipo de narrativa que possibilita ao escritor o exercício de seu tour-de-force, onde ele pode "melhor satisfazer as exigências de grande genialidade". Mas, adverte, "nos referimos à narrativa em prosa curta, que exige de meia hora até uma ou duas horas de leitura atenta". Condena o romance, por perder a força derivada da totalidade:

Os interesses mundanos, que intervêm durante a leitura, modificam, desviam, anulam, em maior ou menor grau, as impressões do livro. Porém, a simples pausa na leitura, por si só, seria suficiente para destruir a verdadeira unidade. No conto breve, no entanto, o autor pode levar a cabo a totalidade de sua intenção, seja qual for. Durante a hora de leitura, a alma do leitor está sob o controle do escritor. ${ }^{10}$

\footnotetext{
${ }^{6}$ POE, Edgar Allan. Essays and reviews. Nova York: Literary Classics of United States, 1984, p. 568.

${ }^{7}$ Ibidem, p. 570.

${ }^{8}$ Ibidem, p. 571.

${ }^{9}$ Ibidem, p. 571.

${ }^{10}$ Ibidem, p. 572.
} 
Poe imagina a criação de um conto por um artista habilidoso. ${ }^{11}$ Não se deve - preceitua ele - amoldar as ideias para acomodar os incidentes, mas, depois de ter concebido um "efeito único e singular", criar os incidentes. Além disso, deve-se combinar tais incidentes de forma a estabelecer o efeito pré-concebido. $\mathrm{Ou}$, como ele afirma, "se a primeira frase não se direciona ao resultado desse efeito, ele já fracassou em seu primeiro passo". Para Poe, a vantagem do conto sobre o romance é que ele permite a unidade de efeito ou de impressão, a leitura totalizadora. A superioridade do conto sobre o poema é que este depende do ritmo para o desenvolvimento de seu ideal mais elevado - que é o da Beleza -, enquanto que aquele depende da Verdade. ${ }^{12}$ Fiel a sua teoria da impressão sobre o leitor, defende os contos de efeito.

Ao analisar contos de Nathaniel Hawthorne que mais o impressionaram, Poe considera "Wakefield" extraordinário pela habilidade com a qual uma ideia antiga é elaborada e discutida. Um homem deixa a mulher e vai morar incognito, por vinte anos, nas proximidades de sua própria casa. O que Poe ${ }^{13}$ valoriza nessa obra é a "análise dos motivos" da loucura do marido e "as possíveis causas de sua persistência". A força da narrativa não advém, pois, do incidente, mas da sua profundidade psicológica, em evidente desacerto com sua própria tese do efeito. ${ }^{14}$ Elogia "The Wedding Knell”, no qual encontra a "mais audaciosa imaginação - uma imaginação completamente controlada pelo bom gosto"; critica o excesso de subentendido em "The Minister's Black Veil" e a obtusidade do misticismo de "The White Old Maid"; considera o assunto de "The Hollow of the Three Hills" um lugar-comum, mas admira-lhe o efeito de economia verbal, na qual "cada palavra diz, e não há palavra que não diz". Ao término dos exemplos, demonstra que algumas passagens de "Howe's Masquerade" foram plagiadas de seu conto "William Wilson". No entanto, com delicadeza, sugere que talvez tudo não tenha passado de "uma coincidência de pensamento muito lisonjeira". Antes de finalizar a segunda resenha, apresenta ainda alguns senões, como o tom de melancolia e misticismo "por demais geral e predominante" e a falta de versatilidade nos assuntos. Elogia a "pureza de estilo", a "força narrativa" e a "alta imaginação" de seu companheiro de ofício.

No texto de novembro de 1847, publicado na Godey's Lady's Book, Poe sugere que Hawthorne tenha alcançado seu limite e, por tratar "todos os assuntos num mesmo tom de cismador innuendo", esteja correndo o risco de ser acusado de maneirista. O amadurecimento do espírito crítico de Poe - cinco anos separavam as primeiras resenhas da terceira - explica a sutil mudança de enfoque. Embora mantenha a admiração, suas reservas aumentaram. Constata que Hawthorne é um exemplo de um homem de gênio admirado na esfera privada, mas desconsiderado pela sociedade em geral:

Sem dúvida, essa indiferença por parte do público origina-se principalmente das duas causas a que já me referi - do fato de ele não ser um homem rico e nem um charlatão; mas isso é insuficiente para explicar a questão toda. Em grande parte isso deve ser atribuído à marcante idiossincrasia do próprio sr. Hawthorne. Em certo sentido, e em grande medida, ser peculiar é ser original. Não há virtude literária maior do que

\footnotetext{
${ }^{11}$ Ibidem, p. 572.

12 Para Mario Lancelotti, a razão de ser dessa preocupação com a questão da verdade como um dos "móveis formais" da história curta já se encontraria nas próprias raízes filológicas do termo. O conto, "que provém de computus", seria "não só recapitulação ou reestabelecimento do fato, senão conta, isto é, 'razão, satisfação de alguma coisa'. Cômputo - que também é calculus - conduz-nos a 'conjetura', que é a sua segunda acepção". Lancelotti ignora, no entanto, as razões ideológicas e histórico-sociais do fenômeno. Durante vinte e cinco séculos, predominou na arte do Ocidente uma vertente reducionista, de visão ético-pedagógica, que valorizou o Bem e o Belo. Somente na metade do século XIX houve uma ruptura nessa mesma visão de mundo, com a emergência de uma perspectiva sociopsicológica. Poe, nos limites de seu romantismo, pode ser considerado um dos precursores dessa transformação. LANCELOTTI, MarioA. "De Poe a Kafka: para una teoría del cuento”. Buenos Aires: Ministerio da Cultura y Educación, 1973. p. 8. ${ }^{13}$ POE, op. cit., p. 572.

14 Julio Cortázar, no ensaio introdutório às Obras en Prosa de Edgar Allan Poe, apontou também para a contradição teórica desta observação. CORTÁZAR, op.cit.
} 
a verdadeira originalidade. Mas esta, tão autêntica como recomendável, não implica uma peculiaridade uniforme, mas sim contínua, uma peculiaridade que nasça de um vigor da fantasia sempre em ação, e ainda melhor se nascer dessa força imaginativa sempre presente, que dá seu próprio matiz e seu próprio caráter a tudo o que toca e, especialmente, que sente o impulso de tudo tocar. ${ }^{15}$

Vemos aqui o quanto se acentuaram, nos últimos anos, as influências românticas sobre Poe. Influências, é certo, que já se manifestavam antes, especialmente no seu radical desprezo pelo realismo, definido por ele como "um excesso nauseante de miniaturas vulgares copiadas da vida cotidiana".

Imaginação, originalidade e vigor da fantasia são palavras de ordem da nova geração de escritores que produz no alvorecer do capitalismo, escritores beneficiados pelos novos e eficientes sistemas de reprodução e distribuição de livros, jornais e revistas. Se, por um lado, como disse Walter Benjamim ${ }^{16}$, a era da reprodutibilidade técnica destruiu a aura do objeto artístico, produziu, por outro, um artista aureolado pela popularidade. Poe, em pleno processo, talvez não pudesse compreender completamente o fenômeno, mas já o intuía, ao recusar a ideia corrente de que os escritores muito originais sempre fracassem em popularidade:

Na verdade, é a excitável, indisciplinada e infantil mente popular que mais aguçadamente sente o que é original. A crítica dos conservadores, dos vulgares, dos velhos clérigos cultos do North American Review é precisamente a crítica que condena, e apenas eles condenam, a originalidade. ${ }^{17}$

No novo mundo em ascensão, mundo da velocidade e da concorrência, não há lugar para os "velhos clérigos cultos", que só desejam quietude e repouso. Quietude e repouso que as narrativas de Hawthorne, representante também do antigo mundo agonizante, ainda ofereciam aos leitores. No entanto, a "excitável, indisciplinada e infantil mente popular" já começava a dispor dos romances-folhetins, que podiam ser lidos com "emoção nova, incomum e aprazível"18. Para o novo Edgar Allan Poe sequer o autor de Twice-told tales é original:

Se o sr. Hawthorne fosse realmente original, ele não poderia falhar em se fazer percebido pelo público. A verdade é que ele não é original em nenhum sentido. Aqueles que falam sobre ele como sendo original, nada mais querem dizer que ele difere no modo e no tom, na escolha dos temas, de qualquer outro autor que conhecem - conhecimento que não se estende ao alemão Ludwig Tieck, cujo modo, em alguns de seus trabalhos, é absolutamente idêntico ao que é habitual para Hawthorne. ${ }^{19}$

Se, por um lado, a referência ao escritor alemão Tieck rebaixa ainda mais a pretendida originalidade de Hawthorne, por outro, demonstra o quanto Poe estava sintonizado com os movimentos literários europeus. ${ }^{20}$ Seu conceito de originalidade adquiriu outras nuanças, mas continua a levar o leitor em consideração:

O elemento da originalidade literária é a novidade. [...] Qualquer coisa que lhe dê (ao leitor) uma emoção nova, incomum e aprazível, é considerado original, e quem frequentemente lhe dá tais emoções, é considerado um escritor original. Numa palavra, é pela soma total dessas emoções que ele decide a respeito da alegação que o escritor faz sobre sua originalidade. ${ }^{21}$

\footnotetext{
${ }^{15}$ POE, op. cit., p. 578.

${ }^{16}$ BENJAMIN, op. cit.

${ }^{17}$ POE, op. cit., p. 579.

${ }^{18}$ Ibidem.

${ }^{19}$ Ibidem, p. 579.

${ }^{20}$ Jorge Luis Borges defenderá Hawthorne da acusação de imitar E. T. A. Hoffmann. Para o argentino, quem pensa tal coisa não leu com atenção nenhum dos dois escritores. BORGES, Jorge Luis. Esse oficio do verso. São Paulo: Companhia das Letras, 2000.

${ }^{21}$ POE, op. cit., p. 579.
} 
Mas a novidade, recorda Poe, pode "cessar de produzir a legítima originalidade" quando a "novidade não se transforma em nada novo" e o escritor, "para preservar a sua originalidade", precipita-se em lugares-comuns. ${ }^{22}$ Segundo ele, a crítica, por "amor a meras palavras", limitou o "literário à originalidade metafísica", além de considerar original "somente aquelas combinações de pensamento, incidentes, e assim por diante, que são, de fato, absolutamente novas". Esse tipo de originalidade "sobrecarrega e choca o intelecto", tornando o escritor impopular para as massas, que estão à procura de divertimento e não de instrução. ${ }^{23}$ A originalidade exigida pela crítica dos conservadores envergonha e perturba, porque falta à massa a capacidade de percepção. O tipo de originalidade, pois, que Edgar Allan Poe tem em mente é outro:

A verdadeira originalidade - verdadeira em relação a seus propósitos - é aquela que, ao fazer surgir as semiformadas, as relutantes ou as inexpressas fantasias da humanidade; ou ao excitar os mais delicados impulsos das paixões dos corações; ou ao fazer nascer alguns sentimentos universais ou instintos embrionários, junta-se assim ao aprazível efeito da aparente novidade, um prazer realmente egoísta. ${ }^{24}$

Por último, critica a tendência alegorizante de Hawthorne. A ideia de que uma alegoria reforce uma verdade é, para Poe, uma falácia. Mesmo nas "melhores circunstâncias", ela interfere na unidade de efeito, "que, para o artista, vale toda a alegoria do mundo". Para ele, a alegoria não tem "nem a metade da afinidade que a substância tem com a sombra" e só é válida quando "o sentido alusivo não interfere com o sentido óbvio do relato". Em A filosofia da composição, afirmou que procurava fazer emergir o simbólico somente ao fim da obra, para que o efeito fosse maior.

Nas três resenhas sobre Hawthorne, Poe não cita Aristóteles, mas considera a verossimilhança o “aspecto mais importante em ficção". Contudo, em sua produção crítica, é possível encontrar, em um artigo de janeiro de 1842, sobre Henry Cockton, um trecho onde Poe 25 transcreve, em grego, a definição de poesia dada pelo filósofo, spoudiokaton kai philosophikotaton genos. ${ }^{26}$ A citação de uma breve passagem da Poética não prova que Poe a conhecesse em profundidade, mas o exame das três referidas resenhas aponta para uma estreita, embora tardia, filiação estética. Tardia porque o apogeu das poéticas inspiradas no estagirita acontecera já durante a segunda metade do século XVIII, na Europa, especialmente com Boileau e Lessing. Ao tempo de Poe, uma nova estética, "nascida com o espírito do grande período da literatura germânica", que enformara os trabalhos de Goethe e Schiller, já abria caminho para a fragmentação das regras e dos gêneros da modernidade, fragmentação que Dilthey ${ }^{27}$ chamou de "colorida mistura de todos os povos e períodos".

O exame das resenhas, de um modo geral, apresenta analogias de pensamento entre Aristóteles e Poe. Em primeiro lugar, o método empregado por ambos é semelhante. De um determinado corpus, a partir da observação, extrai-se um método que se pode chamar de objetivista. Aristóteles, por exemplo, deriva todos os seus princípios da imitação da ação humana; Poe, por sua vez, deriva-os da unidade de impressão ou de efeito sobre o leitor. No limite, a catarse, gerada pelo temor ou pela piedade, já era uma teoria do efeito sobre o espectador. Como em ambas as poéticas a finalidade é apriorística, não surpreende que ambas considerem o plot, os argumentos e as ações das personagens mais importantes que as próprias

\footnotetext{
${ }^{22}$ Ibidem.

${ }^{23}$ Também nesse sentido o século XIX marca a diferença entre a função ético-pedagógica e a sociopsicológica.

${ }^{24}$ POE, op. cit., p. 580.

${ }^{25}$ Ibidem, p. 178.

${ }^{26}$ A poesia é o mais filosófico dos gêneros.

${ }^{27}$ DILTHEY, Wilhelm. Poetry and experience. New Jersey: Princeton University Press, 1985. p. 72.
} 
personagens. A novidade em Poe é que ele aplicou as regras aristotélicas, antes usadas no teatro e na poesia épica, à estrutura da história curta, com resultados e repercussões impressionantes.

\section{Estruturação da poética de Edgar Allan Poe}

A poética de Edgar Allan Poe estrutura-se, pois, sobre:

a. Eixo do procedimento construtivo.

b. Eixo do tratamento dos meios expressivos.

Sob o eixo do procedimento construtivo, o escritor apontou a indevida mistura de gêneros, a pouca diversidade temática, a originalidade dos enredos, a questão da totalidade, da extensão e da tendência de Hawthorne à alegorização, enquanto que, sob o eixo do tratamento dos meios expressivos, preocupou-se com o burilamento da linguagem, a economia verbal e o tom da narrativa - o estilo, mais precisamente.

A crítica de Poe à inclusão de sketches em Twice-told tales remete, em primeiro lugar, a sua preocupação com a depuração dos gêneros, e, em segundo, a sua concepção de obra enquanto todo orgânico e articulado. Rigoroso e sistemático, em 1840, três anos depois da edição dos contos de Hawthorne, intitulará sua própria reunião de histórias curtas de Tales of grotesque and arabesque, onde não incluirá sequer um sketch, fugindo à tradição, que desde Washington Irving, e até mesmo antes dele, assegurava sempre nos livros de ficção curta espaço para esses textos leves e informais. ${ }^{28}$ À época de Hawthorne, segundo seu biógrafo Mark Van Doren, esperava-se que "um sketch fosse típico e discursivo; longe de ser moral ou grave, podia até mesmo ser picante, ou, em todo o caso, completamente secular, com bastante leveza em toda a parte, condizente com seu material leve". ${ }^{29}$

Poe foi o primeiro a perceber que a instauração de um estatuto estético para o conto passava por uma seleção do material a ser reunido. O crítico Herschel Brickell afirma que existem "contos de Tchecov e Mansfield que não podem fugir à designação de sketches mais do que de histórias. A distinção não é tão difícil de ser feita, já que o sketch é estático e o conto dinâmico". ${ }^{30}$ Para William Peden, Poe

concebeu o conto como uma obra de arte, como veículo para a discussão da condição humana e como meio de entretenimento no qual os elementos ficcionais básicos, personagem, incidente, espaço e ideia motivadora, são compacta e inseparavelmente combinados. ${ }^{31}$

Das 39 narrativas lidas por Edgar Allan Poe em Twice-told tales, quais teriam sido consideradas por ele como sketches? Se levássemos em conta sua preocupação constante com o plot, a ausência, às vezes, de incidente e desenlace nos textos de Hawthorne, e se tomássemos como modelo os próprios contos de Poe, já que ele apenas condenou a mistura de gêneros, sem separá-los, diríamos que encontrou onze sketches.

Por sua própria natureza - ausência de plot-, não se pode dizer que haja tempo narrativo no sketch. Melhor talvez fosse falar-se em tempo de descrição. Assim, em sete exemplares de Twice-told tales, o "autor onisciente intruso" enquadrou suas imagens, seus "acontecimentos", em reduzidas unidades temporais como minutos e, num único caso, um dia. Embora tais quadros aconteçam em espaços de tempo determinados, a rigor, são estáticos. Em outros quatro, em que se instaura a figura do narrador, a

\footnotetext{
${ }^{28}$ Meio século depois, certos elementos do sketch retornarão com grande vigor. A sondagem introspectiva e a diluição do enredo serão fatores determinantes na contística cultivada desde Anton Tchecov, a que chamei, em minha tese de doutorado, defendida na Pontifícia Universidade Católica do Rio Grande do Sul, em 2006, de variante da modernidade oriental do conto, em oposição à variante da modernidade ocidental, introduzida por Edgar Allan Poe.

${ }^{29}$ ROSS, Danforth. O conto norte-americano. São Paulo: Martins, 1961.

${ }^{30}$ Ibidem, p. 42.

${ }^{31}$ Ibidem, p. 43.
} 
presença de temporalidade dinamiza as cenas e compõe enredos, embora tênues. No limite, tais textos são formas larvares do tipo de conto que Poe tem em mente. Teriam adquirido outro estatuto se Hawthorne lhes acrescentasse um conflito, uma "transformação psicológica", um pequeno incidente que fosse. A meio caminho entre o sketch puro e o conto, são histórias embrionárias.

É interessante observar o confinamento espacial dos sketches. Ou a descrição parte de um quarto em que se encontra o "autor onisciente intruso" - e nesses casos a janela é o meio de comunicação com o exterior, astúcia do inconsciente do autor para significar o desejo -, ou se reduz a uma praça, praia, montanha ou rua. A alternância de espaços, a sucessão de quadros, traria à descrição a temporalidade imanente da narrativa, transformando o sketch inapelavelmente em conto.

Os temas dos sketches de Hawthorne são genéricos, com forte tendência à descrição de estados de ânimo, conjugados a variações climáticas e de estações: a introspecção e a angústia existencial manifestamse com mais força nos quadros que descrevem o inverno e a chuva, por exemplo. Ao verão e à primavera, correspondem estados psicológicos mais animados e coloridos, inclusive do ponto de vista linguístico. Encontra-se, aqui, um bom exemplo da adequação entre assunto e tratamento dos meios expressivos que Edgar Alan Poe denominou de tom. Enfim, os sketches de Twice-told tales são descritivos, breves e leves, enquadrando-se com perfeição ao modelo em voga no século XIX. Sem plot, sem ação e praticamente sem personagens, são telas, descrições de estados de ânimo, de paisagens naturais e de estações.

Dos 28 contos de Twice-told tales, sete são narrados por eus-testemunha, três por eus-protagonista, onze por narradores oniscientes, seis por narradores-intrusos e um por narrador autor-editor, conforme a tipologia de Friedman. No conjunto de histórias, por exemplo, de Province-House - Howe's masquerade, Edward Randolph's portrait, Lady Eleanore's mantle e Old Esther Dudley -, o narrador não testemunha os fatos, mas reconta-os a partir da narração do mordomo, que se poderia chamar de homem-narrativa, na expressão de Tzvetan Todorov. Temos, assim, a narração dentro da narração, ou o encaixe, recurso de antiga tradição.

Por outro lado, em The gray champion e em The Wedding-Knell, os próprios descendentes dos atores das tramas são os narradores. Recontam histórias que ouviram. E, por fim, o uso do narrador autoreditor em "Wakefield". O narrador dessa peça singular é um eu-leitor, que reconta uma história lida num jornal londrino. Ele faz uma acurada análise das motivações psicológicas do protagonista, área de grande interesse para Poe. Não importa se a notícia é verdadeira ou não, se o jornal realmente existiu, ou se foi inventado por Hawthorne, importa, sim, o procedimento narrativo. Num futuro distante, Jorge Luis Borges utilizará a mesma técnica com frequência. A originalidade do conto não se encontra no enredo, nem sua unidade de efeito é conseguida pela sequência peripécia-reconhecimento. Desde o primeiro parágrafo, o leitor conhece o plot, do princípio ao fim. O que ele lê é a detalhada análise dos motivos da ação do senhor Wakefield. Onde estaria, assim, o gancho de interesse? Na sutil exploração do desejo inconsciente do leitor de abandonar também os seus deveres, sua vida regrada, e viver fora, à distância, numa morte aparente? Poe trabalhou fartamente, em seus próprios contos, com esse desejo.

Em The vision of the fountain, o narrador é o próprio protagonista, narrando em primeira pessoa. Já em The seven vagabounds e em Chipping with a chisel temos narradores que participam da trama como personagens secundários e que recontam as histórias que vivenciaram.

O narrador de Little Annie's ramble, embora seja também um eu-testemunha, possui um componente de onisciência paradoxal: como se fosse o anjo-da-guarda de Annie, acompanha-a, de cima, como uma câmera, descrevendo todos os seus movimentos. Tal narrador, contudo, não se enquadra no narradorcâmera de Friedman, já que se prevê para esse tipo de técnica o máximo de exclusão do narrador na 
transmissão de flashes da realidade como que apanhados por uma câmera. E o que temos aqui é o máximo de inclusão do narrador.

Não se pode negar que o exame dos enredos comprova a crítica de Poe a respeito da tendência alegorizante de Hawthorne. Quando a fábula não é alegórica, o narrador encarrega-se de lembrar ao leitor que é necessário ler-se aí um outro sentido. No entanto, nesse jogo que é o conto, em que cada elemento da história é subordinado à ação em conjunto, e o conjunto subordinado às determinações históricas, $\mathrm{o}$ que para Poe foi um defeito, para nós, contemporaneamente, pode ser uma virtude.

Para Walter Benjamin ${ }^{32}$, a alegoria é uma "representação do outro" e necessita ser reativada para que seu contexto histórico adquira significação. Assim, por exemplo, o conto The gray champion precisa ser lido como alegoria dirigida aos leitores do século XIX, como mitificação de lendas históricas e geográficas dos colonizadores da Nova Inglaterra. Desenraizada, a história do Paladino grisalho - na tradução brasileira -, alegoria do espírito libertário da população puritana, perde em atrativo. No entanto, recontextualizada, emerge como "ruína da história", monumento linguístico aos heróis anônimos responsáveis pela libertação norte-americana do jugo da coroa britânica. A alegorização levada a efeito por Hawthorne faz recuperar o caráter épico da revolução, historiciza-a e fixa-a em um espaço e um tempo bem delimitados. A alegoria como que dá um endereço à História e torna possível localizar a luta particular dos puritanos no universo das lutas contra as opressões. ${ }^{33}$

Longamente excluída, acusada por Hegel $^{34}$ de ser uma "produção fria e nua", a figura retórica que diz o outro precisou esperar o advento de um pensador do porte de Walter Benjamin para recuperar espaço. O próprio Hawthorne, em carta ao amigo Fields, de 1854, afirma não "ter certeza de compreender perfeitamente" o que quis dizer "nalgumas dessas malditas alegorias". ${ }^{35}$ Para o biógrafo Mark Van Doren, ${ }^{36}$ contudo, não poderia haver "maior loucura em matéria de crítica do que negar o poder dessas coisas só pelo fato de tratar-se de poder simbólico". É interessante, ainda, observar a opinião que tem Hawthorne a respeito da tendência alegórica de seus sketches, em artigo publicado em 1851:

Eles têm a pálida tonalidade de flores que desabrocharam numa sombra retirada demais - a frialdade do hábito da meditação que se difunde pelo modo de sentir e de observar em cada sketch. Em vez de paixão, há sentimentalismo; mesmo naquilo que pretende ser pintura da vida atual, encontramos alegoria, nem sempre calidamente coberta com trajes de carne e sangue, para poder ser lida sem um estremecimento. Não se sabe se por falta de poder, ou por uma invencível reserva, as pinceladas do autor dão de vez em quando uma impressão de fraqueza; o mais alegre dos homens mal consegue rir de sua maior pilhéria; a mais terna das mulheres não derramará lágrimas, nos trechos mais tristes. Para se ver alguma coisa no livro,é preciso que ele seja lido na atmosfera pouco nítida, marrom, crepuscular em que foi escrito. ${ }^{37}$

A veemente recusa que Poe faz das alegorias hawthornianas tem um polo oposto, sua defesa do símbolo. O escritor que afirmou, no final de A filosofia da composição, que o leitor devia "encarar o corvo como simbólico", não podia valorizar o uso frequente de alegorias em seu conterrâneo, tão embebido estava dos ideais românticos. No entanto, as alegorias dão aos contos de Hawthorne uma inquietante modernidade, contos que, de certa forma, pavimentam o caminho para outros alegoristas, como Charles Baudelaire e Franz Kafka.

\footnotetext{
${ }^{32}$ BENJAMIN, op. cit.

${ }^{33}$ Para Hegel e Goethe, somente os símbolos seriam representações dos “universais concretos”. A querela é interminável. Dependendo do contexto histórico, e portanto da ideologia, valoriza-se o símbolo em detrimento da alegoria, e vice-versa.

${ }^{34}$ HEGEL, G. W. F. Estética. Lisboa: Guimarães Editores, 1993.

${ }^{35}$ DOREN, Mark Van. Nathaniel Hawthorne. São Paulo: Martins Fontes, 1967, p. 63.

${ }^{36}$ LUBBOCK, Percy. A técnica da ficção. São Paulo: Cultrix/Edusp, 1976.

${ }^{37}$ DOREN, op. cit., p. 62.
} 
Destacamos que, em nossa análise dos enredos, evitamos a oposição simbólico versus alegórico e optamos pela oposição alegórico versus realista. Para nossos propósitos, realista não se refere à escola literária de mesmo nome, mas caracteriza a narração que reproduz a causalidade natural, narração que se atém à representação, que não exige do leitor dobras de significação, cujos enredos não remetem a simbolizações. Nesse aspecto, os contos fantásticos, que têm uma causalidade não natural, uma outra lógica interna, são classificados como alegóricos.

Se nos sketches de Twice-told tales constataram-se o confinamento espacial e o estreitamento temporal, nos contos, por outro lado, o espaço e o tempo são ampliados e variam conforme a necessidade do narrador de utilizar a cena ou o sumário. Na definição do crítico inglês Percy Lubbock ${ }^{38}$, na cena, em que o narrador não deve fazer intervenções, os acontecimentos são mostrados (showing) ao leitor e no sumário o narrador conta (telling) os fatos e os resume. No primeiro caso, o tratamento é dramático e, no segundo, pictórico. Tomemos exemplos de cena e de sumário no conto The minister black's veil. Logo ao início, e como que à distância, o narrador pinta o ambiente (espaço carregado de características sociais, econômicas, morais, psicológicas e culturais em que se movimentam os personagens), e instaura o clima dominical:

Estava o sacristão no alpendre da igreja de Milford, puxando diligentemente as cordas do sino. Os velhos da aldeia vinham curvados pela rua afora. Crianças de rostos risonhos caminhavam alegremente ao lado dos pais, ou arremedavam um andar mais austero, cônscias da dignidade de suas roupas de domingo. Solteirões alinhados olhavam de soslaio para as bonitas garotas, imaginando que o sol domingueiro as fazia ainda mais bonitas do que nos dias de semana. ${ }^{39}$

A essa cena, como que aproximando o leitor da narrativa - alternando também o tempo verbal - de um distante pretérito imperfeito para um perfeito mais próximo no tempo, segue-se um sumário:

Quando o povo em sua maior parte se reuniu no alpendre, o sacristão começou a tocar o sino, espichando a vista para a porta da casa do reverendo Hooper. O primeiro indício do vulto do ministro era o sinal para o sino deixar de tocar sua chamada. - Mas o que tem o pároco Hooper diante do rosto? - perguntou de súbito, atônito, o sacristão. Todos quantos ouviram a pergunta se voltaram para fitar o sr. Hooper, que, a passo lento e com um ar pensativo, se dirigia para a casa de oração. $O$ espanto foi unânime, e não exprimia mais perplexidade, caso algum ministro estranho estivesse chegando ali para espanar o pó das almofadas do sr. Hooper. ${ }^{40}$

Imediatamente depois dessa cena, um sumário fornecerá ao leitor outras informações sobre o sr. Hooper, seu estado civil, idade, detalhes mais precisos sobre o estranho véu. Nova cena vem quebrar a monotonia da descrição, dinamizando a narrativa. Até o final do conto, cenas e sumários vão se alternando.

São frequentes em Twice-told tales os símbolos controladores, também utilizados pelos romancistas góticos, tais como John Neal, Charles Brockden Brown, William Godwin, Mrs. Radcliffe, Horace Walpole e Maturin: o retrato misterioso, o pergaminho embolorado, o vilão deformado, o crime secreto, o elixir proibido, a busca esotérica, o riso do diabo, o olhar reluzente, a palavra agourenta. ${ }^{41}$

Além dos procedimentos construtivos, que dizem mais respeito à estrutura das próprias narrativas de Twice-told tales, Edgar Allan Poe observou, ainda, nas suas resenhas, o tratamento dispensado pelo escritor de Salem aos meios expressivos, relacionados diretamente com a linguagem.

\footnotetext{
${ }^{38}$ LUBBOCK, op. cit.

${ }^{39}$ HAWTHORNE, Nathaniel. Tales and sketches. New York: Library of America, 1984, p. 21.

${ }^{40}$ Ibidem, p. 21.

${ }^{41}$ DOREN, op. cit., p. 36.
} 
Segundo os biógrafos de Hawthorne, entre eles Mark Van Doren e Raymona Hull, que tiveram acesso aos originais do autor, ele burilava seus contos incansavelmente. No entanto, o que Poe chamou de economia verbal, passado mais de um século e meio, transformou-se, para os padrões atuais, em prolixidade. Ocorre que Poe tem em mente outros autores do período, como Irving e Melville, ou mesmo Scott e Brown, que são bem mais verborrágicos e descuidados em suas narrativas do que Hawthorne. Seu estilo, "tão lento, tão lamuriento, tão misterioso", como o caracterizou Doren, reproduz o contexto histórico e social de Salem. Além das muitas leituras de autores góticos, conforme atestam seus cadernos de apontamentos, há que se considerar também o clima intelectual da Nova Inglaterra onde viveu, carregado de teorias unitaristas e transcendentalistas. As cenas crepusculares de tantos de seus enredos podem ser, como o aponta a crítica, pastiches de Scott, e sua tendência a usar situações de fundo histórico podem ter o velho historiador Cotton Mather como fonte, mas isso não diminui o prazer que ainda hoje nos proporciona a leitura de Twice-told tales, nem retira de Hawthorne o mérito de ter sido, junto com Poe, um dos "mestres iniciadores da short story americana". ${ }^{42}$

Edgar Allan Poe tem uma concepção de fatura de livro de contos que leva em consideração até mesmo o título da obra. Há, nessa postura, uma evidente preocupação com o leitor, o que demonstra o quanto estava atento às novas relações sociais no interior da sociedade capitalista. Nela, o leitor é um consumidor do produto artístico, e não quer e não pode ser enganado. O título, proclama o contista, deve fazer referência a tudo que a obra contém. Sketches são sketches, contos são contos. Poe intitulou sua própria coleção de histórias curtas de Tales of grotesque and arabesque e pretendeu, dessa forma, ser fiel ao seu conteúdo.

O exame das narrativas revela, em primeiro lugar, o acerto do autor a respeito do título da obra, que faz referência a tudo que ela contém. Observemos, inicialmente, a expressão grotesco. O adjetivo, por si só, e que define o que é monstruoso, anormal, e até o que é ridículo, não dá conta da sutileza da escolha de Edgar Allan Poe. Atento aos duplos sentidos, ele o escolheu também por sua origem etimológica. Grottesco é o estilo utilizado por pintores renascentistas, como Rafael Sanzio e Giovanni da Udine, e que anuncia o advento do Romantismo. Segundo Aurélio Buarque de Holanda Ferreira, ${ }^{43}$ a palavra italiana "originou-se na imitação de ruínas de edificações descobertas no século XIV, em Roma, e que foram tidas como grutas; nelas se encontraram pinturas que retratavam, sob forma de arabescos e linhas sinuosas, homens e animais". Mais que definir o tema de alguns contos, como "A queda da casa de Usher", "O barril de Amontillado", "O gato preto", "Berenice”, "Manuscrito encontrado numa garrafa", "William Wilson", "Metzengerstein”, "Nunca aposte sua cabeça com o diabo", "O poço e o pêndulo" e "Uma descida ao Maelstrom”, Poe ainda se dá ao luxo de brincar com um requintadíssimo detalhe: os arabescos dentro das grutas.

Tomemos, ainda, o outro termo, arabesco. Há, no vocábulo, duas acepções básicas. A primeira é a de ornato de origem árabe, em que se entrelaçam flores, frutos, grinaldas, ramagens e linhas; a segunda é a de rabisco, garatuja. A primeira gerou o adjetivo exótico e é para essa significação que o autor orientou sua atenção quando, em dezembro de 1839, publicou a coletânea de contos. Haveria, para a época, algo mais exótico do que aqueles cinco contos de raciocínio, que dariam origem a um novo gênero de literatura, "Os crimes da Rua Morgue", "O assassinato de Marie Roget", "A carta roubada", "O escaravelho de ouro" e "O jogador de xadrez de Maelzel"? Haveria algo mais exótico do que a descida, na Terra, de um extraterrestre redondo e sem orelhas, como o

\footnotetext{
42 Ibidem, p. 35.

${ }^{43}$ FERREIRA, Aurélio Buarque de Holanda. Novo Aurélio. Rio de Janeiro: Nova Fronteira, 1999.
} 
que aparece em “A aventura sem paralelo de um tal Hans Pfaall”? Ou a própria viagem de Pfaall à Lua, a bordo de um balão? Nesse conto, embora distante, conserva-se um pouco do orientalismo da expressão, já que a aventura de Pfaal pode ser lida como uma paródia da viagem marítima de Simbad, o marujo. Assim, comprova-se o rigor do título escolhido por Poe a sua própria coletânea de histórias. Dos dezesseis textos, dez são contos grotescos e seis são arabescos.

Lembremos que Poe, em sua crítica a Twice-told tales, apontou aspectos sobre o procedimento construtivo, como a pureza do gênero, a pouca diversidade temática, a originalidade dos enredos, a questão da totalidade e da extensão, a alegorização. ${ }^{44} \mathrm{E}$ se fizermos o caminho inverso, aplicando a sua poética aos seus contos?

Sobre o primeiro aspecto, seu rigor é exemplar. Mesmo quando tende à dissertação, como no preâmbulo de "Os crimes da Rua Morgue", em que faz um demorado exame das faculdades mentais analíticas, ela é absolutamente funcional e enquadrada no contexto maior da narração. Tales of grotesque and arabesque são contos, exclusivamente. Mesmo "O jogador de xadrez de Maelzel”, baseado em fatos reais, e que poderia ser visto como uma reportagem investigativa é uma short story. Emoldurando a descrição e a análise da fraude do autômato, temos um narrador e um enredo com sua dupla face, a fábula e o assunto. $\mathrm{O}$ fato de que a base da história seja histórica pouco importa, já que o define um gênero é sua estrutura. Poe não incorre no defeito de Irving e Hawthorne, que reuniram indistintamente esboços, sketches e contos em suas coletâneas. De certo modo, essa “especialização", de que seu livro é modelar, reflete o início do surto de desenvolvimento capitalista de uma América industrial que terá no fordismo e na produção seriada a contraparte econômica dessa opção estética.

Os temas de Tales of grotesque and arabesque vão desde a clássica história de aventura, inovada por não ocorrer mais no mar, mas no espaço sideral, até o crime de vingança, a fraude, o furor da natureza, a busca do tesouro escondido, a tortura por motivos ideológicos, o misticismo popular, a chantagem política, a metempsicose, o estupro, a violência animal, a esquizofrenia, a fantasmagoria, a monomania, a obsessão paranoica, o incesto, a catalepsia e a fria racionalidade. Um espectro temático extraordinário, a que se soma uma multiplicidade espacial e geográfica impressionante, que vai de catacumbas e calabouços a escarpas e montanhas, passando por mares e gabinetes, mansões e castelos, estalagens e salões artísticos; das pradarias da América do Norte à Espanha, Inglaterra, França, Itália, Hungria, Noruega, chegando ao Polo Ártico. Esse internacionalismo, essa universalidade eram os indícios antecipatórios do novo mundo que estava nascendo nas placas de impressão dos caracteres tipográficos das revistas e dos jornais e nos pistões e mancais das locomotivas a vapor.

Os enredos de Poe são originais tanto na fábula (o que efetivamente ocorreu), como no assunto (a maneira pela qual o leitor toma conhecimento disso). Retomemos o conceito de originalidade defendido pelo escritor bostoniano, não sem antes lembrar de Freud, para quem o terror só é possível diante do já-conhecido, mas ainda não-formulado. Para Poe, a originalidade verdadeira, diferente da simples novidade, faz surgir as semiformadas, relutantes e inexpressas fantasias da humanidade porque elas excitam os mais delicados impulsos das paixões e fazem nascer os sentimentos universais ou instintos embrionários. Que outro nome daríamos a isso, senão retorno do reprimido? O que há de mais inexpresso na consciência humana do que o desejo de vingança, de morte, de incesto, de necrofilia e de tantos outros sentimentos "semiformados" e "relutantes", como os que sentem e que executam as próprias personagens de Poe? Seus enredos são originais se lidos na perspectiva que ele próprio estabeleceu, e que só se pôde realmente compreender com o advento da psicanálise. Sem os conceitos de consciente, inconsciente, ego, alterego, neurose, psicose,

\footnotetext{
${ }^{44}$ POE, op. cit.
} 
esquizofrenia, obsessão, clivagem, pulsão, deslocamento, transferência, lapso, condensação, introversão, complexo, significante, estranheza, suas histórias reduzem-se a fantasias românticas, nascidas de um cérebro superexcitado pelo álcool e pelo ópio, ou a frutos decadentes de suas leituras dos autores góticos, Hoffmann, Kleist e Tieck. Fossem elas apenas isso, não teriam permanecido no imaginário artístico por tanto tempo. A rigor, elas são o anúncio profético de um novo tempo, as sementes que germinaram a estética da desventura - como a chamou Octávio Paz -, ${ }^{45}$ na qual a "exceção, a beleza irregular, é a verdadeira regra”, e com o que se minaram "as bases éticas e metafísicas do classicismo", abrindo passagem à modernidade.

Se William Shakespeare inventou o humano, como o afirmou Harold Bloom, ${ }^{46}$ Edgar Allan Poe inventou o homem moderno, esse centauro desesperado, meio máquina, meio homem, meio anjo, meio fera.

Dos dezesseis contos de Tales of grotesque and arabesque, sete são protagonizados pelos narradores, oito são por eles testemunhados, e um, "Metzengerstein", como que fazendo contraponto ao narrador de "Wakefield", de Hawthorne, é uma história editada, recontada. No entanto, em Poe, o uso da técnica autoreditor é um elemento de composição da representação, já que a fábula é inventada. Hawthorne baseou-se em história real, um caso ocorrido em Londres e noticiado pela imprensa da época. Imaginava estar fazendo um sketch, um comentário autoral de cunho moralístico, uma reflexão edificante. Seu conto só adquiriu estatuto estético a posteriori, ao passo que Poe criou a lenda, localizando-a na Hungria, e para dar-lhe aparência de verdade, para construir a verossimilhança, espalhou pelo texto referências a livros reais, históricos, método que viria a ser amplamente utilizado por Jorge Luis Borges, um século depois. São três, pois, os tipos de narradores na obra em estudo, conforme a tipologia de Friedman: eu-protagonista, eu-testemunha e autoreditor, com absoluta predominância dos dois primeiros e com a exclusiva voz narrativa em primeira pessoa. ${ }^{47}$ O narrador autor-editor, na verdade, é um subtipo, pois podemos entender a leitura como um testemunho, já que ler uma história, e recontá-la, é uma forma de fazer parte dela, com os evidentes acréscimos e supressões que tal processo comporta. Esse tipo de narrador, que em Hawthorne e em Poe é ainda forma embrionária, em Borges virá a adquirir estatuto de função organizadora do relato. ${ }^{48}$

Ao examinarmos a questão da totalidade e da extensão dos contos, é necessário retornar às correlações de pensamento entre Poe e Aristóteles. O filósofo grego afirmou, na Poética, que não poderia ser belo algo de dimensão reduzida, porque a visão tornar-se-ia confusa, nem poderia ser belo algo que fosse imenso, pois faltaria ao espectador a visão de conjunto, que permite contemplar a unidade e a totalidade. Por isso, para Aristóteles, os mitos devem ter uma extensão que a memória consiga reter. O limite, de uma tragédia deve ser o tempo necessário para que se dê a passagem da infelicidade para a felicidade ou vice-versa. Poe apenas não faz referência, na sua transposição do conceito, à memória, por desnecessário. O novo mundo industrial, o mundo da rapidez das locomotivas, é um mundo construído sobre as bases da linguagem escrita. O conto moderno não é um causo, para ser decorado e recontado, mas um texto. E um texto não precisa ocupar espaço na memória, ele pode ser reacessado a qualquer instante, basta abrir o livro e ler, enquanto a paisagem desliza pela janela do vagão. O relativismo da extensão de uma assentada como média ideal para o formato de uma história curta abre a possibilidade para sua redução na direta proporção do aumento da velocidade, como efetivamente ocorreria na história do conto. Hoje, temos não apenas as

\footnotetext{
${ }^{45}$ PAZ, Octavio. La casa de la presencia. México: Círculo de Lectores/FCE, 1995, p. 65.

${ }^{46}$ BLOOM, Harold. A angústia da influência. Uma teoria da poesia. Rio de Janeiro: Imago, 1991.

${ }^{47}$ Apenas três dos protagonistas têm nome: Montresor, em "O barril de Amontillado", Egeu, em "Berenice”, e William Wilson, no conto homônimo. Observe-se, ainda, que este último é um pseudônimo.

${ }^{48}$ Para Iuri Tinianov (Teoria da Literatura. Lisboa: Edições 70, 1987, p. 133), nenhum elemento literário desaparece com a automatização, com o desgaste provocado pelo seu uso excessivo, mas apenas muda de função, que se torna auxiliar. Neste caso, a função auxiliar passou a ocupar a posição de função principal.
} 
sudden-stories, como também minicontos, microcontos, nanocontos etc. ${ }^{49}$ De certa forma, Poe inventou a relatividade literária, ao conjugar o tamanho do texto com a aceleração do tempo de leitura. No novo mundo, não há mais espaço para as composições vagarosas de Irving e Hawthorne. O leitor, que trocou as lentas carruagens pelos rápidos trens, quer conhecer o destino de seus heróis antes da chegada à estação. Fiel as suas premissas, Poe, nas dezesseis histórias de Tales of grotesque and arabesque, não decepciona.

Não se pode compreender a crítica de Poe à tendência alegorizante de Hawthorne, nos primórdios da era da reprodutibilidade técnica, sem se recuperar a imagem de alegoria no contexto daquela sociedade. $\mathrm{Na}$ Nova Inglaterra de clérigos fundamentalistas, ela é uma forma literária desgastada, sem força transformadora. E é contra isso que Poe se insurge. Ele não quer que a literatura sirva a propósitos religiosos, a lições de moral. Em nossa análise, observamos que tanto os enredos de Hawthorne como os de Poe, às vezes, são alegóricos. Em Poe, no entanto, eles perderam o caráter ético-pedagógico. A literatura não quer mais ensinar, mas divertir. Se, através do prazer, alguém vier a aprender alguma coisa, tanto melhor. ${ }^{50}$

O segundo eixo criado por Poe para a análise de Hawthorne, o do tratamento dos meios expressivos, leva em consideração o burilamento da linguagem, a economia verbal e o tom. A escritura de Hawthorne, Melville, Thoreau, Emerson, entre outros norte-americanos de meados do século XIX, é herdeira das formas do diário e do sermão e satisfaz às necessidades do velho mundo pré-industrial, mas, para expressar o novo mundo eletroquímico, é necessário reduzir a "pletora verbal", dar à frase um andamento mais firme e mais rápido. ${ }^{51}$ Escrever, enfim, numa linguagem mais funcional. E é o culto da brevidade, da intensidade e da unidade de efeito que possibilita essa modificação profunda no tecido verbal narrativo.

Embora a alternância de tipos de personagens em Tales of grotesque and arabesque seja pequena, a linguagem transforma-se substancialmente de um conto para outro. Em "A queda da casa de Usher", por exemplo, há um uso da antropomorfização que não se verá em nenhuma outra história. É que a palavra serve aos propósitos alegóricos da trama: a mansão é um ser vivo e em decomposição. A linguagem de "A aventura sem paralelo de um tal Hans Pfaall” é carregada de termos técnico-científicos, enquanto que os quatro contos de raciocínio, protagonizados pelos narradores-detetives, o francês Dupin e o franco-americano Legrand, são escritos com clareza e coerência cartesianas. Já "O poço e o pêndulo" e "O gato preto", que mergulham no inconsciente, são narrados com metáforas obscuras, carregadas de simbologias e antinomias.

Num estilo econômico e num tom que se adequa sempre ao enredo, em que a palavra é precisa, Poe, conforme relata Quiroga, ${ }^{52}$ deu um dos maiores exemplos de honestidade intelectual e de integridade moral da história da literatura: num tempo em que os escritores recebiam por página, recusou a prolixidade, as descrições panorâmicas e desenlaces folhetinescos, para concentrar-se em histórias curtas, com controle formal. Preferiu receber, em vida, seis dólares, em média, por conto, para ser digno, no futuro, da admiração apaixonada dos grandes contistas que ajudou a formar.

Recebido em: 17/03/2015

Aprovado em: 06/06/2015

\footnotetext{
${ }^{49}$ Augusto Monterrosso, conhecido mundialmente, é autor de um conto de sete palavras: "Quando acordou, o dinossauro ainda estava lá".

${ }^{50}$ Não devemos nos esquecer que Poe não abriu mão da Verdade.

${ }^{51}$ NESTROVSKI, Arthur Rosenblat. Debussy e Poe. Porto Alegre: L\&PM, 1986.

${ }^{52}$ QUIROGA, Horacio. A honestidade artística. In: Biografias Exemplares. Porto Alegre, L\&PM, 2002.
} 